\begin{tabular}{|l|l|l|}
\hline \multicolumn{2}{|c|}{ PublisherInfo } \\
\hline \hline PublisherName & $:$ & BioMed Central \\
\hline \hline PublisherLocation & $:$ & London \\
\hline \hline PublisherImprintName & $:$ & BioMed Central \\
\hline \hline
\end{tabular}

\title{
Modelling a signalling module
}

\begin{tabular}{|l|l|l||}
\hline \multicolumn{2}{|c|}{ ArticleInfo } \\
\hline \hline ArticleID & $:$ & 4633 \\
\hline \hline ArticleDOI & $:$ & $10.1186 /$ gb-spotlight-20021112-01 \\
\hline \hline ArticleCitationID & $:$ & spotlight-20021112-01 \\
\hline \hline ArticleSequenceNumber & $:$ & 299 \\
\hline \hline ArticleCategory & $:$ & Research news \\
\hline ArticleFirstPage & $:$ & 1 \\
\hline \hline ArticleLastPage & $:$ & 2 \\
\hline \hline & & RegistrationDate : 2002-11-12 \\
ArticleHistory & $:$ & OnlineDate \\
\hline \hline ArticleCopyright & $:$ & BioMed Central Ltd2002-11-12 \\
\hline \hline ArticleGrants & $:$ & \\
\hline \hline ArticleContext & $:$ & 130593311 \\
\hline \hline
\end{tabular}




\section{Jonathan B Weitzman}

Email: jonathanweitzman@hotmail.com

The NF- $\mathrm{KB}$ transcription factor plays a critical role in regulating cell growth, cell survival and the

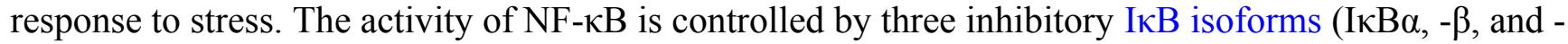
$\varepsilon)$ that regulate NF-kB cellular localization. In the November 8 Science, Hoffmann et al. describe a computational modelling approach to understanding NF-kB regulation (Science 2002, 298:1241-1245). They constructed a computational model that incorporates multiple control parameters including the rate of synthesis of each IkB isoform, the formation and stability of binary and tertiary protein complexes, cellular localization and transport rates. The model predicts an oscillatory NF- $\mathrm{KB}$ activation profile created by negative feedback regulation loops. Analysis of mouse fibroblasts lacking combinations of I $\mathrm{KB}$ genes revealed that the different isoforms function to modulate fast and slow responses to inflammatory stimuli and are responsible for distinct gene expression programs.

\section{References}

1. NF-kB: a pleiotropic mediator of inducible and tissue-specific gene control.

2. NF-KB and Rel proteins: evolutionarily conserved mediators of immune responses.

3. Science, [http://www.sciencemag.org] 